\title{
Application of powder injection molding process to manufacturing of Ni-ZrO2 anodes in Solid Oxide Fuel Cells
}

\section{A. Mirahmadi M. Rezaee Saraji, ${ }^{1}$}

Solid oxide fuel cells (SOFC) are a promising high-efficient power generating system that can directly convert chemical fuel to electrical power. Cost reduction of materials and processing is one of the key issues for commercialization of SOFCs. SOFCs, as the electrochemical devices consist of anode and cathode, separated by the ion conducting material called electrolyte. The main SOFC element is anode, whose function, apart from oxidation the hydrogen, is to carry the mechanical loads which occur in the whole cell. Anode features the cell skeleton supporting electrolyte and cathode. Due to the rising interest in SOFC a high demand for them in future is expected, therefore, one should use the powder forming method applicable for mass production of such elements. Powder injection molding is the best solutions in this case. This method offers the possibility of fabricating tubes or plates which can be assembled into packets making increase of the SOFC power possible.

Powder injection molding (PIM) is a manufacturing technology for the net-shape production of small, intricate, and precise metal or ceramic components. The PIM process includes mixing of either metal or ceramic powders with a binder to produce a feedstock, injection molding to form a green part with the desired shape by making the feedstock flow into and fill a mold under pressure, debinding to form a brown part by removing the binder components, and sintering to near full density.

The powders ( $\mathrm{NiO}$ and $\mathrm{ZrO} 2)$ were mixed with a binder system which consists of stearic acid (SA), polypropylene (PP) and paraffin wax (PW). Mixing of components was done using two blades at the temperature of $170^{\circ} \mathrm{C}$ at the speed of $40 \mathrm{rpm}$. Five selected mixtures of powders with binder are studied. Rheological characterization of all type of feedstocks were performed in a Rheoflixer capillary rheometer at 170,180 and $190^{\circ} \mathrm{C}$ over a range of shear rates from 10 to $10000 \mathrm{~s}^{-1}$. Feedstocks were injected on the injection molding machine to make the test pieces. The debinding process of green samples was made by two different steps. First the injected samples were debound in a bath with the heptanol and next by thermal debinding. The sintering process took place immediately after the debinding. Debound pieces were sintered by heating from 1150 to $1450^{\circ} \mathrm{C}$ and by soaking at these temperatures for one hour. Results of the rheological and torque investigations have essential importance for further search of the optimum feedstock to injection molding machines making forming possible of shapes for fuel cells anodes, which require in addition debinding of the binder and sintering. High viscosity of the feedstock in which there are hard ceramic particles cause fast wear of screws, dies, heads, and cylinders of injection molding machines and extruders, therefore binder portion increase is required. One may state based on bending strength tests and density examinations of the sintered and reduced anodes that the sintering temperature should not be lower than $1250^{\circ} \mathrm{C}$. Lower sintering temperature deteriorates significantly mechanical properties of anodes which perform also the mechanical load carrying function for the whole fuel cell.

1 m_rezaee@mecheng.iust.ac.ir

This is an Open Access article distributed under the terms of the Creative Commons Attribution-Noncommercial License 3.0, which permits unrestricted use, distribution, and reproduction in any noncommercial medium, provided the original work is properly cited. 